\title{
KONSTYTUCYJNE PODSTAWY WOLNOŚCI RELIGIJNEJ W WYBRANYCH PAŃSTWACH EUROPY I AMERYKI ŁACIŃSKIEJ
}

Słowa kluczowe: wolność religijna, konstytucja, Ameryka Łacińska, Europa

Keywords: religious freedom, constitution, Latin America, Europe

1. WSTĘP

eligia jest zjawiskiem, które wypełnia człowiekowi sferę potrzebną do zachowania jego własnej tożsamości oraz uczestnictwa we wspólnym dziedzictwie ${ }^{3}$. Współcześnie wolność religijna jest powszechnie gwarantowana w konstytucjach państw europejskich. Jest to konsekwencją tego, że od wieków relacje między państwem a religią warunkowały proces kształ-

\footnotetext{
${ }^{1}$ Katedra Prawa Wyznaniowego i Konkordatowego, Instytut Prawa Międzynarodowego, Unii Europejskiej i Stosunków Międzynarodowych, Wydział Prawa i Administracji, Uniwersytet Kardynała Stefana Wyszyńskiego w Warszawie.

2 Katedra Prawa Konstytutcyjnego, Instytut Prawa Międzynarodowego, Unii Europejskiej i Stosunków Międzynarodowych, Wydział Prawa i Administracji, Uniwersytet Kardynała Stefana Wyszyńskiego w Warszawie.

3 J. Peteva, Religion In Bulgaria at the beginning of the XXIst century, „European Journal for Church and State Research" 7 (2000), s. 298.
} 
towania się społeczeństwa. Dyskusje o państwie i religii prowadziły do wyznaczenia ram działania władzy politycznej i decydowały o statusie jednostki w państwie ${ }^{4}$.

Ze względu na znaczenie wolności religijnej w kształtowaniu państwa i społeczeństwa, przedmiotem opracowania będzie przedstawienie konstytucyjnych podstaw wolności religijnej w wymiarze indywidualnym w wybranych państwach Europy i Ameryki Łacińskiej. Celem analizy jest wskazanie sposobu sformułowania przepisów o tej wolności oraz ich treści. Porównanie poszczególnych rozwiązań ma określić podobieństwa i różnice w kształtowaniu wolności religijnej wybranych państw Europy i państw Ameryki Łacińskiej, a przez to przesądzić czy istnieją określone standardy w tym zakresie.

W pierwszej kolejności zostaną wskazane konstytucyjne podstawy wolności religijnej we Włoszech, Hiszpanii i Portugalii. Wybór tych państw jest podyktowany tym, że uczestniczyły one w kształtowaniu nowożytnej Ameryki Łacińskiej. Następnie zostaną omówione podstawy prawne wolności religijnej w Argentynie, Chile i Kolumbii. We wszystkich państwach wybranych do analizy wyznaniem dominującym jest wyznanie rzymskokatolickie.

\section{WoLnOŚĆ RELIGIJNA W PAŃSTWACH EUROPEJSKICH}

We współczesnej Europie państwo ma charakter co do zasady świecki. Nie istnieje jednak jeden model relacji państwa do związku wyznaniowego. Idea rozdziału między sferą państwową a religijną może być określana w różny sposób, począwszy od akcentowania neutralności, przez wskazywanie autonomicznego charakteru władzy świeckiej i religijnej aż po wprowadzenie obok niezależności państwa i związku wyznaniowego elementu współdziałania. Wolność religijna w wymiarze indy widualnym jest zależna od respektowania zasady pluralistycznego społeczeństwa ${ }^{5}$.

Podstawowe treści charakteryzujące relacje demokratycznego państwa prawa wobec religii można znaleźć przede wszystkim w aktach między-

${ }^{4}$ M. Safjan, Wolność religijna w konstytucjach państw europejskich, [w:] Religia i wolność religijna w Unii Europejskiej, red. J. Krukowski, O. Theisen, TN KUL, Lublin 2002, s. 43.

${ }^{5}$ Ibidem, s. 45. 
:::: M. Osuchowska, A. Syryt, Konstytucyjne podstawy wolności...

narodowych, w tym w art. 9 Konwencji o ochronie praw człowieka i podstawowych wolności, zgodnie z którym: „Każdy ma prawo do wolności myśli, sumienia i wyznania. Prawo to obejmuje wolność zmiany wyznania lub przekonań oraz wolność uzewnętrzniania indywidualnie lub wspólnie z innymi, publicznie lub prywatnie, swego wyznania lub przekonań przez uprawianie kultu, nauczanie, praktykowanie i obrzędy"6.

Odzwierciedlenie tych treści można spotkać w konstytucjach państw europejskich. Przeprowadzona analiza pozwala stwierdzić, że określone standardy ochrony wolności religijnej są współtworzone przez państwa Europy oraz wspólnotę międzynarodową.

\subsection{W WOCHY}

Konstytucja Republiki Włoskiej z 22 grudnia 1947 r. obszernie reguluje wolność religijną. Z orzecznictwa włoskiego Trybunału Konstytucyjnego wynika, że prawa sumienia są duchową bazą kulturową oraz podstawą wartości etyczno-prawnych każdej innej wolności i innych praw podstawowych?

Jedna z zasad naczelnych konstytucji włoskiej stanowi, że wszyscy obywatele są równi w godności i w prawie, bez względu między innymi na religię (art. 3). W świetle art. 19 tego aktu, każdy ma prawo do wyznawania i szerzenia swojej wiary w jakiejkolwiek formie, indywidualnie lub zbiorowo oraz prawo do sprawowania kultu prywatnie lub publicznie. Art. 19 i 20 konstytucji włoskiej wprowadzają jednak zastrzeżenie, że praktykowanie religii czy też kult nie mogą się wyrażać w obrządkach sprzecznych z prawem lub dobrymi obyczajami oraz z moralnością publiczną.

$\mathrm{Z}$ art. 19 konstytucji włoskiej wynika więc, że wolność religijna przysługuje „każdemu”, a nie tylko „obywatelowi”. Przepis ten stanowi nie tylko prawo do religii np. związane z jej wyznawaniem, budowaniem miejsc kultu, posiadaniem cmentarzy, praktykowaniem. Wynika z niego również wolność od religii, z jedynym ograniczeniem, którym jest działanie wbrew moralności publicznej. Wobec powyższego, zadaniem art. 19 konstytucji włoskiej jest ochrona poglądów odnoszących się do sumienia. Chodzi

${ }^{6}$ Konwencja o ochronie praw człowieka i podstawowych wolności, sporządzona w Rzymie dnia 4 listopada 1950 r. - Dz.U. z 1993 r., nr 61, poz. 284 z późn. zm.

7 Zob. Orzeczenia włoskiego TK z 1991 r., nr 467 oraz z 1997 r., nr 43. 
również o takie poglądy, które są związane z ateizmem i agnostycyzmem. W prawie tym mieszczą się także kwestie dotyczące odmowy dokonywania określonych czynności ze względu na sumienie ${ }^{8}$.

Do wolności religijnej nawiązuje pośrednio również art. 21 konstytucji włoskiej, z którego wynika wolność ekspresji. Prawo wyrażania przekonań moralnych i filozoficznych jest bowiem nierozerwalnie związane z realizacją wolności religijnej.

Z orzecznictwa włoskiego Trybunału Konstytucyjnego wynika, że państwo powinno gwarantować wolność religijną w ramach wyznaniowego i kulturowego pluralizmu9.

Jak wskazał Rocco Buttiglione, konstytucja jest nie tylko dokumentem, który określa zasady organizacji władzy publicznej. Autor podkreślił, że jest to również akt określający fundamentalne wartości, które warunkują byt narodu oraz określają tożsamość jednostki ${ }^{10}$. Z tego względu kwestia wolności religijnej określonej w konstytucji musi być interpretowana w kontekście celu, jaki ta wolność ma spełniać. W szczególności chodzi o to, by w pluralistycznym społeczeństwie różne wizje, religie i ludzkie doświadczenia znalazły przestrzeń do debaty i urzeczywistniania.

\subsection{HISZPANIA}

Konstytucja hiszpańska z 1978 r. różni się regulacją wolności religijnej od innych konstytucji europejskich ${ }^{11}$. Jest to wynikiem zachodzących przemian systemu ustrojowego tego państwa od wyznaniowego do świeckiego. Mimo że odejście od państwa wyznaniowego nastąpiło w Hiszpanii wiele

${ }^{8}$ A. Ferrari, S. Ferrari, Religion and the secular state: Italian Case. National Report: Italy, [w:] The Italian National Reports to the 18th World Congress of Comparative Law, red. P. G. Montaeri, „The Cardozo Electronic Law Bulletin”16 (2010), nr 1 (numer specjalny), s. 435-436.

9 Zob. orzeczenie włoskiego TK z 1989 r., nr 203.

10 R. Buttiglione, Freedom of religion in Italy. Problems and challenges, [w:] Universal Rights in a World of Diversity - The Case of Religious Freedom, „Pontifical Academy of Social Sciences" 17 (2012), s. 323.

${ }_{11}$ Religious Freedom in Spain. Updating the law?, „Revista de Fomento Social” 2009, nr 255, s. 1. 
:::: M. Osuchowska, A. Syryt, Konstytucyjne podstawy wolności...

lat temu, to proces budowania wieloreligijnego modelu współistnienia trwa do dziśín .

Art. 16 konstytucji hiszpańskiej zawarty w rozdziale II tytule pierwszym „Prawa podstawowe i wolności o charakterze publicznym” stanowi, że gwarantowana jest wolność ideologiczna, religijna i kultu po stronie jednostki, jak i wspólnot bez jakichkolwiek ograniczeń, wyłączywszy tylko te ograniczenia, które są niezbędne do utrzymania porządku publicznego stanowionego przez prawo. Jednocześnie przepis ten stanowi, że nikt nie może być zobowiązany do deklarowania swojej ideologii, swojej religii i swojego wyznania.

Konstytucja hiszpańska nie wskazuje wprost w swych przepisach na wolność sumienia i wyznania, na wzór aktów prawa międzynarodowego i wielu konstytucji państw europejskich. Akt ten odnosi się do „wolności ideologicznej", która jest pojęciem szerszym.

Hiszpański Trybunał Konstytucyjny podkreślał, że wolność sumienia jest jednym z przejawów „wolności ideologicznej” i należy przez nią rozumieć nie tylko prawo do swobodnego kształtowania swoich poglądów, ale też prawo do zachowania w sposób odpowiadający własnym przekonaniom ${ }^{13}$.

Hiszpańscy konstytucjonaliści rozważają czy na gruncie art. 16 konstytucji mamy do czynienia z jednym prawem gwarantowanym w różnych jego aspektach, czy z trzema odrębnymi prawami ${ }^{14}$. Orzecznictwo Trybunału hiszpańskiego nie jest w tym zakresie jednolite. Zwykle jednak wolność religijna jest określana jako konkretyzacja wolności ideologicznej, a jednocześnie jako podstawowe prawo jednostki, które umożliwia jej określenie swej tożsamości.

Prawo do wolności religijnej jest rozwijane w przepisach ustawowych. Jest nią hiszpańska ustawa organiczna z dnia 5 czerwca 1980 r. o wolności

${ }^{12}$ F. Diez de Velasco, History of Religions in Spain and SECR (Sociedad Española de Ciencias de las Religiones/ Sanish Association for the Sicences of Religions), „Bandue. Revista de la Sociedad Española de Ciencias de las Religiones” 2009, nr 3, s. 123.

${ }_{13}$ Zob. Wyrok hiszpańskiego TK z 15 stycznia 1982 r.

${ }_{14} \mathrm{Tj}$. prawem do wolności ideologicznej, prawem do wolności religijnej i prawem do wolności kultu. Zob. R. Mendizabal Allende, C. Viver Pi-SUnyer, J. Carlos Duque Villanueva, Jurisprudence constitutionnelle en matiere de liberte confessionnelle. Report du Tribunal Constitutionnel de l'Espagne, [w:] Constitutional jurisprudence in the area of freedom of religion and belifes. XIth Conference of the European Constitutional Courts, red. Office of the Constitutional Tribunal, Warsaw 2000, s. 719 i n. 
religijnej, w której powtórzono konstytucyjne gwarancje wolności religijnej, a także uregulowano sprawy dotyczące pozycji Kościoła i wyznania ${ }^{15}$.

Główną zasadą tej ustawy, rozwijającą konsty tucyjną regulację związaną z wolnością ideologiczną, jest wolność religijna. Oznacza ona, że państwo w zakresie spraw dotyczących religii musi chronić fundamentalne prawo, które akty międzynarodowe nazywają wolnością myśli i sumienia, a art. 16 konstytucji hiszpańskiej określa jako wolność ideologii, religii i kultu. Zasada wolności jest ważna ze względu na jej wymiar i wpływ na kształtowanie statusu jednostki w państwie ${ }^{16}$.

Drugą zasadą, która jest związana z religią jest ta odnosząca się do równości. Chodzi tu o zapewnienie ochrony różnym wyznaniom i religiom na równych zasadach, a tym samym o zapobieganie dyskryminacji ${ }^{17}$.

Trzecia zasada dotyczy neutralności w sprawach religijnych i jest traktowana jako główne narzędzie konstytucyjne do ochrony wszystkich jednostek i grup religijnych w realizacji ich wolności ${ }^{18}$.

Należy podkreślić, że art. 9 ust. 2 konstytucji hiszpańskiej wskazuje zobowiązanie władz publicznych do stworzenia warunków umacniających wolność i równość jednostki i grup, do których taka jednostka należy. Zagwarantowanie wolności, w tym wolności religijnej, nie może polegać jedynie na powstrzymywaniu się państwa od ingerencji. Przeciwnie, organy władzy publicznej, zgodnie z wymogami konsty tucji hiszpańskiej, muszą stwarzać przestrzeń i warunki do realizacji tej wolności, a także gwarancje jej ochrony ${ }^{19}$.

\subsection{Portugalia}

Konstytucja Republiki Portugalii z 2 kwietnia 1976 r. zawiera przepisy o wolności religijnej ukształtowane w podobny sposób, jak w wielu konstytucjach państw europejskich. Regulacja ta jest dość rozbudowana. Oprócz

\footnotetext{
${ }^{15}$ Ley Organica 7/1980, July 5, 1980 de Libertad Religiosa. Obecnie są zgłaszane propozycje zmian w tej ustawie.

${ }^{16}$ J. Martínez-Torrón, Religious Freedom and Democratic Change in Spain, „BYU Law Review" 2006, nr 3, s. 785.

17 Ibidem.

18 Ibidem, s. 786-787.

19 Z. Combalia, M. Roca, Religion and the Secular State of Spain, [w:] National Report: Spain 2014, s. 631.
} 
:::: M. Osuchowska, A. Syryt, Konstytucyjne podstawy wolności...

wyraźnego przepisu gwarantującego wolność religijną w wymiarze indywidualnym, odniesienia do religii są też zawarte $\mathrm{w}$ innych fragmentach konstytucji portugalskiej ${ }^{20}$.

Art. 13 konstytucji portugalskiej, wskazujący na zasadę równości, określa religię, jako kryterium, które nie może służyć dyskryminacji. Z kolei art. 19 przewiduje możliwość zawieszenia korzystania z praw człowieka w sytuacji zagrożenia państwa, ale ust. 6 tej regulacji stanowi, że w takim stanie nadzwyczajnym w żadnym wypadku nie można naruszać wolności sumienia i religii.

Konstytucja portugalska odnosi się do religii również w kontekście stosowania nowych technologii i wykorzystywania danych. Art. 35 ust. 3 tego aktu stanowi, że komputery nie mogą być wykorzystywane do zbierania danych na temat wierzeń religijnych jednostek. W tym zakresie muszą być stworzone określone gwarancje ochrony.

Regulacją bezpośrednio odnoszącą się do wolności sumienia, religii i kultu jest art. 41 konstytucji portugalskiej. Wynika z niego, że wolność religijna nie może być naruszana (ust. 1). Określona regulacja ma wymiar pozytywny i negatywny. Z jednej strony zakłada bowiem zakaz prześladowania, pozbawienia praw, ale też zwalniania z obywatelskich obowiązków ze względu na przekonania religijne (ust. 2). Nie można zmuszać jednostki do wyjawienia swoich przekonań religijnych. Jeśli natomiast zbierane są dane dotyczące kwestii wyznania lub religii, a także przekonań, nie mogą być one ujawniane w sposób umożliwiający identyfikację danego podmiotu. Można je przedstawiać jedynie w ramach danych statystycznych (ust. 3).

Ponadto art. 41 ust. 4 konstytucji portugalskiej zapewnia separację Kościołów i związków religijnych od państwa, w tym wolność w samostanowieniu tych podmiotów oraz wolność wykonywania obrzędów i sprawowania kultu. Art. 41 ust. 5 konstytucji zapewnia wolność nauczania religii, w tym wolność wykorzystywania różnych środków służących temu celowi. Dodatkowo w ust. 6 art. 41 gwarantuje możliwość korzystania z klauzuli sumienia.

\footnotetext{
${ }^{20}$ J. de Sousa e Brito, Religion and Discrimination Law in Portugal, s. 1-6, http://www. law.cf.ac.uk/clr/research/National\%20Report\%20(Portugal).pdf (dostęp: 12.05.2016).
} 
Zgodnie z art. 43 ust. 3 konstytucji portugalskiej, państwo nie może zakładać zgodności programów kształcenia lub działań kulturalnych z określonymi dyrektywami filozoficznymi, ateistycznymi, politycznymi, ideologicznymi lub religijnymi. Oznacza to, że w ramach wolności nauczania władze publiczne nie mogą narzucać nikomu określonego światopoglądu ani religii.

Wolność religijna jest też uwzględniona w przepisach dotyczących politycznych zrzeszeń i partii. Art. 51 ust. 3 konstytucji stanowi, że partie polityczne nie mogą przyjmować nazw, które bezpośrednio byłyby związane z określonym związkiem wyznaniowym lub religią. To samo tyczy się używania znaków tych organizacji i symboli o charakterze religijnym.

Art. 59 ust. 1 zakłada gwarancje pracownicze, niezależnie od wyznawanej religii.

Należy podkreślić zatem, że wolność religijna jest obecna w wielu przepisach konstytucji portugalskiej, a kryterium religii nie może być przyczyną dyskryminacji w przyznawaniu określonych praw, w tym w zapewnieniu ochrony praw, wynikających z ustawy zasadniczej.

\section{Wolność religijna w państwach Ameryki Łacińskiej}

W regionie Ameryki Łacińskiej, przyjmując tradycyjną i najbardziej akceptowaną definicję podziału na państwa konfesyjne i akonfesyjne ${ }^{21}$, jedynie Kostaryka jest państwem wyznaniowym ${ }^{22}$. Wszystkie pozostałe kraje są

${ }^{21}$ Zob. J. Martínez-Torrón, W. Cole Durham, Jr., Religion and the Secular State (La religion et l'Etat laïque) General Rapporteurs, [w:] Religion and the Secular State (La religion et l'État laïque), Interim National Reports (Rapports Nationaux Intermédiaires) issued for the occasion of The XVIIIth International Congress of Comparative Law (Le XVIIIe Congrès international de droit comparé), The International Center of Law and Religion Studies, Washington D. C. 2010, s. 1-56; W. Cole Durham, Jr., Religious Freedom in a Worldwide Setting: Comparative Reflections, [w:] Universal rights in a world of diversity: the case of religious freedom, red. M. A. Glendon, H. F. Zacher, „The Pontifical Academy of Social Sciences. Acta 17", Pontificia Academia Scientarum Socialium, Vatican City 2012, s. 365-367.

${ }^{22}$ A. Maroto Vargas, La confesionalidad del Estado costarricense: un proceso en constante renovación (The confessionality of the Costa Rican state: a process in constant renovation, „Revista Reflexiones” nr 92 (2013), nr 2, s. 189-198. 
:::: M. Osuchowska, A. Syryt, Konstytucyjne podstawy wolności...

świeckie, chociaż poziom zróżnicowania pomiędzy nimi w zakresie akceptacji zjawiska religijność jest duży ${ }^{23}$.

Należy podkreślić, że w konstytucjach państw latynoamerykańskich czynnik religijny ma szczególne znaczenie, niezależnie od tego czy wprost wymieniają one religię katolicką, Kościół katolicki czy też nie odnoszą się do żadnego konkretnego wyznania ${ }^{24}$. Najczęściej uznaje się w ustawach zasadniczych „wolność sumienia”, „wolność religii” i „wolność kultu”; pojęcia te są też stosowane przez doktrynę prawa konstytucyjnego i wyznaniowego. W niektórych prawodawstwach występuje jednak wyłącznie „wolność kultu", co stanowi element podstawy państwa laickiego jednocześnie akcentując tę sferę w relacjach instytucjonalnych ${ }^{25}$.

Niezmienne na przestrzeni lat pozostaje umieszczanie w preambułach konstytucji latynoamerykańskich formuły invocatio Dei. W żadnej z nich nie przybrała ona jednak uroczystej formuły. Wolność sumienia i religii została redakcyjnie wyłączona z regulacji relacji państwo - Kościół. Instytucjonalne normy prawa wyznaniowego w niewielu przypadkach połączono z prawem jednostki do wolności sumienia i religii ${ }^{26}$.

Wolność sumienia i religii jako prawo podstawowe, wzorem konstytucji państw demokratycznych z innych regionów świata, jest gwarantowane także w państwach latynoamerykańskich. Najczęściej pojawia się w nich sformułowanie „każdy człowiek”27.

${ }^{23}$ Największe różnice zauważyć można pomiędzy Argentyną, którą część doktryny uznaje za państwo quasi-wyznaniowe z uwagi na art. 2 konstytucji przyznający specjalny status i gwarancje Kościołowi katolickiemu, a Meksykiem, w którym relacjom państwo - Kościół przez wiele lat przyświecała idea wrogiego laicyzm, obecnie w nieco złagodzonej wersji opartej na rozdziale tych dwóch podmiotów.

${ }^{24}$ C. Asiain Pereira, Religion and religions in the Latin American Constitutional framework, [w:] Law, religion, constitution: freedom of religion, equal treatement, and the law, red. C. Cianitto, W. Cole Durham Jr, S. Ferrari, D. Thayer, Ashgate, Aldershot 2013, s. $125-149$.

${ }^{25}$ W. Bar, Kwestie wyznaniowe w konstytucjach krajów Ameryki Łacińskiej i Karaibów, [w:] Prawo wyznaniowe w systemie prawa polskiego. Materiały z I Ogólnopolskiego Sympozjum Prawa Wyznaniowego (Kazimierz Dolny, 14-16 stycznia 2003), red. A. Mezglewski, TN KUL, Lublin 2004, s. 144-146; R.F. Domínguez, La libertad religiosa en el marco de los derechos humanos. Su expresión legislativa en América Latina y el Caribe, Centro de Estudios sobre América, Havana 2005, s. 34-37.

26 Ibidem, s. 149-150.

27 W Argentynie znajdujemy rozróżnienie na „mieszkańca kraju” (art. 14) i „obcokrajowca" (art. 20). 


\subsection{Argentyna}

Wolność religijna jest podstawową zasadą prawa wyznaniowego w Argentynie. Wyraża się ona w wielu normach i jest stosowana we wszystkich gałęziach prawa.

Konstytucja od 1853 r. gwarantuje wolność kultu (art. 14) oraz wolność sumienia (art. 19). Mamy tutaj do czynienia jednak z wyjątkowym systemem relacji, bo pomimo tego, że ludzie są równi co do zakresu praw im przysługujących, w tym zwłaszcza praw fundamentalnych, to w odniesieniu do instytucjonalnego wymiaru wolności religijnej pierwszeństwo wśród wyznań przyznane zostało Kościołowi katolickiemu (art. 2). Mimo to w Argentynie nie ma oficjalnej religii, a państwo to uznaje pełną wolność kultów, chociaż bez ich równouprawnienia ${ }^{28}$. Akty prawa międzynarodowego ratyfikowane przez Argentynę dodatkowo wzmocniły opiekę państwa nad prawem do wolności religijnej. Warto podkreślić, że w momencie uchwalania tych przepisów wolność kultów była negowana oraz ograniczana praktycznie na całym świecie, także przez nauczanie Kościoła katolickiego.

Konstytucja gwarantuje w art. 14 prawo do „wolnego wyznawania swojego kultu" wszystkim mieszkańcom. Norma ta została powtórzona (zbytecznie) odrębnie dla obcokrajowców w art. 20. Wolność kultu należy interpretować w sposób szeroki, wykraczający poza samo manifestowanie w formie uzewnętrzniania. Celem zapewnienia w pełni wolności religijnej uwzględnić trzeba również sferę wewnętrzną, do której zaliczamy wolność sumienia ${ }^{29}$.

Ochrona wyżej wymienionego prawa, jako zasada niedyskryminacji z powodów religijnych, także znajduje się w porządku prawnym. Taka postać dyskryminacji jest sama w sobie przestępstwem, ale również okolicznością obciążającą w stosunku do każdego innego czynu karalnego.

W zakresie wolności sumienia, poza uregulowaniami konstytucyjnymi, można odnaleźć stosowne normy wprost wpisane w akty różnych ga-

28 A. Gabino Ziulu, Las relaciones entre el Estado y la Iglesia, La Ley 1991-E, 1527.

${ }^{29}$ J. G. Navarro, Floria, N. Padilla, O. Lo Prete, Derecho y religión. Derecho eclesiástico argetino, Editorial de la Universidad Católica Argentina, Buenos Aires 2014, s. 70-71. 
:::: M. Osuchowska, A. Syryt, Konstytucyjne podstawy wolności...

łęzi prawnych ${ }^{30}$. Sposób ujęcia tego zagadnienia pozwala na szeroką jego ochronę $\mathrm{w}$ formie rozubudowanych klauzul sumienia: wojskowej, medycznej (w tym dotyczącej zdrowia reprodukcyjnego), w odniesieniu do symboli patriotycznych. W wielu innych wypadkach została ona zagwarantowana poprzez orzecznictwo, tj. w prawie pracy, przy składaniu przysięgi, poddawaniu się zabiegom medycznym sprzecznym z sumieniem ${ }^{31}$.

Stosownie do art. 14 konstytucji wolność religii jest ograniczona „ustawami, które określają ich wykonywanie". Na uwadze należy mieć także normę wyrażającą ogólną zasadę, zgodnie z którą limitowanie praw ma być rozsądne i nie powinno naruszania ich istoty (art. 28). Do materialnych podstaw ograniczania praw religijnych zalicza się z kolei porządek i moralność publiczną.

Warto podkreślić, że orzecznictwo sądów argentyńskich, federalnych i narodowych, w zakresie szeroko pojętej wolności religijnej jest liczne. Każda z dwudziestu czterech prowincji posiada kompetencje w tej materii, dotyczące głównie zagadnień z obszaru edukacji, pomocy religijnej w zakładach karnych i szpitalach, zwolnień podatkowych i in. ${ }^{32}$ Sam termin „wolność religijna” zaczął pojawiać się dopiero od czasu reformy Sądu Najwyższego w $1983 \mathrm{r}^{33}$

\subsection{CHILE}

Konstytucja chilijska uznaje wolność sumienia i religii w wymiarze indywidualnym (art. 19 ust. 6) wskazując jednocześnie prawne podstawy jej ograniczania. Szczegółowy katalog praw indywidualnych, w tym wolność sumienia, chroniony jest poprzez specjalne środki zaskarżenia - skargę ochronną będącą formą skargą konstytucyjną, przeprowadzaną w procedurze przy-

${ }^{30}$ Zob. J. G. Navarro Floria, El derecho a la objeción de conciencia, Abaco, Buenos Aires 2004.

${ }^{31}$ J. G. Navarro Floria, Derecho eclesiastico y libertad religiosa en la Republica Argentina, [w:] Estado, Derecho y Religión en America Latina, red. J. G. Navarro, Marcial Pons Argentina, Floria, Buenos Aires-Madyt-Barcelona 2009, s. 55-56.

${ }^{32} \mathrm{~W}$ dwóch prowincjach (Santa Fe, Catamarca) religia katolicka uzyskała szczególną pozycję.

${ }_{33}$ Zob. Sprawa Portillo Alfredo, Corte Suprema de Justicia de la Nación Argentina (CSJN), 18/4/89. 
spieszonej. Pierwsze konstytucje chilijskie ${ }^{34}$ zawierały wyłącznie przepisy dotyczące instytucyjnych relacji religii państwowej-katolickiej, rzymskiej, apostolskiej. W 1925 r. (art. 10) po raz pierwszy wskazano rozdzielenie państwa od Kościoła i zagwarantowano wolność kultu i sumienia ${ }^{35}$.

Z normy zawartej w art. 19 konstytucji możemy wyodrębnić trzy uprawnienia przyznane każdemu człowiekowi: wolność sumienia, wolność przekonań religijnych oraz wolność sprawowania kultu. Należy uznać zatem, że istnieje prawo do wierzenia albo niewierzenia, które wynika ze swobodnego myślenia, manifestowania, przynależności (albo też nie) do konkretnego wyznania. Jest to sfera wewnętrzna jednostki, dlatego jest prawem bezwzględnym. $\mathrm{Z}$ drugiej strony można wyprowadzić z powyższego przepisu także prawo do wolności opinii i informacji. W obszarze wolności religijnej nie może być ono ograniczone w sytuacjach stanów nadzwyczajnych, na przykład stanach wyjątkowych. Nie ma jednak wyraźnego przepisu dotyczącego tej kwestii w konstytucji. Ponadto wolność kultu, także należna każdemu człowiekowi, jest prawem autonomicznym i niezależnym od przymusu do realizacji czynów lub aktów o charakterze zewnętrznym, które mają na celu oddawanie czci Bogu. Jednakże nie jest to prawo o charakterze absolutnym, gdyż posiada ograniczenia zakreślone przez ustrojodawcę do sprzeczności z moralnością, dobrymi obyczajami lub porządkiem publicznym ${ }^{36}$.

Prawo do wolności religijnej, a zwłaszcza formy jego uzewnętrzniania, podlegają dużej debacie w obrębie doktryny chilijskiej, głównie w zakresie określenia treści wolności sumienia a także uregulowania klauzuli sumienia jako prawa konstytucyjnego. Konstytucja nie ustanawia wprost prawa do sprzeciwu sumienia. Gdyby przyjąć zatem wyłącznie perspektywę pozytywistyczną, to należałoby uznać, że w Chile prawo do sprzeciwu sumie-

\footnotetext{
${ }^{34}$ Konstytucje z lat: 1818, 1823, 1828, 1833.

$35 \mathrm{~W}$ preambule pozostawiono jednak inwokację a w przepisach przejściowych zagwarantowano przez okres pięciu lat dostarczanie do arcybiskupa Santiago de Chile kwotę 2,5 mln pesos rocznie na potrzeby rozwijania kultu Kościoła katolickiego. Konstytucja ta przyznawała Kościołowi i jego jednostkom organizacyjnym także osobowość publicznoprawną.

${ }^{36}$ H. T. Aravena, Bases constitucionales de la libertad de conciencia y culto en Chile, „Revista de Derechos Fundamentales” 2012, nr 7, s. 87-115.
} 
:::: M. Osuchowska, A. Syryt, Konstytucyjne podstawy wolności...

nia nie istnieje. Tutaj należy posłużyć się jednak art. 5 ust. 2 konstytucji, który wprowadza pewne domniemanie prawne ${ }^{37}$.

W Chile nie wyróżnia się wprost wolności religijnej, a tylko „wolność sumienia, prawo do manifestacji wszystkich przekonań i swobodnego korzystania ze wszystkich kultów, które nie są sprzeczne z moralnością, dobrymi obyczajami lub porządkiem publicznym". Mimo to należy uznać, że w tej kwestii prawo międzynarodowe, a także ustawa wyznaniowa z 1999 r. będąca ustawą organiczną, w praktyce regulują wolność i równość w sferze religijnej.

Rozumienie wyrażenia „wiara” użytego przez Konstytuantę jest szersze niż tylko dotyczące wymiaru religijnego. Dlatego w pojęciu „wierzenia” zawarta jest także „religia”. Religie są zwykle rozumiane w sposób tradycyjny, obejmujący co najmniej „credo, rytuały i doktrynę” ewentualnie jej główne elementy, tj. akt wiary, doktrynę, manifestację i zaangażowanie moralne. Wierzenia jednak są mniej restrykcyjne i odnoszą się zasadniczo do powstawania spójnego punktu widzenia na podstawowe problemy egzystencjalne. Mają znaczenie dla sfery moralnej. We współczesnym rozumieniu wolności religijnej skupionej na osobie, nie jest istotna "jakość” jej wierzeń ani to czy stanowią one prawdę, czy też fałsz. Wolność religijna dystansuje się od tego rodzaju ocen, bo z samej godności człowieka wynika prawo do swobodnego tworzenia przekonań bez jakiegokolwiek przymusu ${ }^{38}$.

Inne, nierozstrzygnięte zagadnienia, na gruncie prawa wyznaniowego, to wolność myśli, która nie została wpisana do konstytucji. Uznaje się, że prawo to można wyprowadzić z aktów międzynarodowych dotyczących praw człowieka ratyfikowanych przez Chile.

\subsection{Kolumbia}

Konstytucja Kolumbii z 1991 r. zawiera inwokację, której sformułowanie oznacza uznanie przez państwo Boga za fundamentalne źródło wszystkich instytucji prawnych. Nie wskazuje przy tym żadnej konkretnej religii. Na-

37 Szerzej na ten temat zob.: H. Nogueira Alcalá, La libertad de conciencia, la manifestaciónde creencias y la libertad de culto en el ordenamiento jurídico chileno, „Revista Ius et Praxis" 12 (2006), nr 2, s. 13-41; F. H. Campos, Historia Constitucional de Chile, Editorial Universitaria, Santiago de Chile 2005, s. 366-367.

${ }^{38}$ J. Pizarro Precht, Estudios sobre Libertad Religiosa en Chile, Ediciones Pontificia Universidad Católica de Chile, Santiago 2006, s. 21-39. 
leży jednak skłonić się ku tezie, że czynnik religijny jest ujęty w konstytucji w formie pozytywnej. Konstytucja ta, w przeciwieństwie do wszystkich poprzednich, nie określa Kolumbii jako państwa wyznaniowego ${ }^{39}$.

Bezpośrednio do wolności religijnej, klasycznej triady uprawień: wolność myśli, sumienia i religii, odnoszą się kolejno następujące po sobie trzy artykuły znajdujące się w ty tule II rozdziale 1 dotyczącym praw podstawowych: art. 18 - wolność sumienia; art. 19 - wolność kultów/religii; art. 20 - wolność myśli. Przepisy te odnoszą się do wolności przysługujących jednostce z uwagi na jej przekonania. Brak jest natomiast w ustawie zasadniczej bezpośredniego odwołania do relacji pomiędzy państwem a związkami religijnymi. Pierwszy z artykułów gwarantuje wolność sumienia oraz zakaz prześladowań ze względu na przekonanie lub wyznanie. Kolejny z nich wprowadza wolność kultów, a tym samym również prawo do praktykowania swojej religii w formie grupowej, skąd wynika także zasada równouprawnienia wyznań i Kościołów. Wolność myśli ujęta została natomiast w trzeciej kolejności, łącznie z prawem do wyrażania opinii.

W obowiązującej ustawie zasadniczej nie brakuje innych przepisów odnoszących się do zagadnienia wolności religii w szerokim ujęciu. Już w pierwszym artykule konstytucji wyraźnie zaznaczone zostało, że władza państwowa opiera się na „poszanowaniu godności człowieka, na pracy i solidarności jednostek, które ją tworzą i na nadrzędności interesu ogółu". Obowiązek ochrony przez władze państwowe wszystkich osób przebywających na terytorium kraju, wprost wskazany został w art. 2 konstytucji. Dotyczy on także ochrony przekonań tych podmiotów. Zasada równości wszystkich ludzi, wpisana w art. 13 konstytucji, jako jedno z kryteriów niedyskryminacji (równości i sprawiedliwości społecznej) wymienia religię. Powiązanie wyznawanej wiary z wieloma dziedzinami życia społecznego spowodowało, że z punktu widzenia wolności religijnej ważne są również inne przepisy konstytucyjne, np. te dotyczące prawa małżeńskiego i rodzinnego - art. 42, które wprowadzają uznanie skutków cywilnych dla małżeństw kościelnych. Oddzielnie określono prawo rodziców do wychowywania religijnego małoletnich dzieci - art. 68 konstytucji.

39 F. A. Ramos Castañeda, Derecho fundamental de libertad religiosa constitucional y jurisprudencial de la República de Colombia: análisis histórico y régimen jurídico, Universidad de San Dámaso, Madrid 2014, s. 160-162. 
:::: M. Osuchowska, A. Syryt, Konstytucyjne podstawy wolności...

W konstytucji kolumbijskiej podmiot prawa do wolności religijnej został określony w sposób negatywny poprzez użycie wyrażenia „nikogo nie można prześladować", a contrario prawo do wolności sumienia i wyznania przysługuje zatem wszystkim. W przypadku wolności kultów ustawodawca posłużył się już natomiast wprost zaimkiem „każdy”, co nie pozostawia żadnych wątpliwości, co do jego intencji. Podobnie skonstruowany został kolejny artykuł przyznający wolność ekspresji, który rozpoczyna się od słów „każdej osobie”, co jeszcze bardziej podkreśla personalistyczne spojrzenie prawodawcy na podmiot praw, jakim jest człowiek. Ponadto nawiązał on do istoty godności, która jest źródłem wszelkich praw i wolności jednostki, a władza państwowa opiera się na jej poszanowaniu. Nie wskazano w konstytucji samej genezy godności człowieka ani jej pochodzenia.

Określając zakres przedmiotowy wolności myśli, sumienia i kultów w ujęciu indywidualnym, konstytucja nie definiuje ich, a sam ich obszar działania wyjaśniony został w bardzo ogólny sposób. Co do zasady, poza regulacją prawną pozostaje samo pojęcie wolności myśli oraz sumienia, które jako elementy powiązane ze sferą wewnętrzną człowieka, są niemożliwe do skutecznego uregulowania ich za pomocą norm prawnych. Swobodny wybór światopoglądu, niezależnie od tego czy jest on oparty na religii, czy pozostaje areligijny, nie może podlegać z samej natury rzeczy przepisom prawnym, których zadaniem jest normowanie aktów zewnętrznych, w tym przypadku manifestowania już wybranego wcześniej zespołu przekonań ${ }^{40}$.

\section{Podsumowanie}

Podsumowując powyższe rozważania należy stwierdzić, że wolność religijna jest prawem człowieka chronionym zarówno w konstytucjach państw Europy, jak i w konstytucjach państw Ameryki Łacińskiej, chociaż sposób ujęcia tego prawa w aktach normatywnych nie jest jednolity.

Fakt zawarcia przepisów o wolności religijnej w wymiarze indywidualnym w konstytucjach jest wynikiem określonych podobieństw systemu europejskiego i latynoamerykańskiego. Wspólnymi cechami obu systemów jest to, że Europa i Ameryka Łacińska należą do tzw. cywilizacji zachodniej.

40 Ibidem, s. 181-184. 
Systemy prawne krajów latynoamerykańskich ukształtowały się przede wszystkim na gruncie prawa rzymskiego. Największy wpływ na ten system miały zaś Hiszpania i Portugalia.

Należy podkreślić, że to co pozwoliło wyznaczyć ramy wolności religijnej to wspólna religia, jaką jest chrześcijaństwo. Nie można pominąć też roli Kościoła katolickiego, którego działania były wyrazem łączenia obu kontynentów w różnych wymiarach już od czasów kolonialnych.

Zarówno wspólna religia, jak i podobieństwo podstaw prawnych funkcjonowania poszczególnych państw były tymi czynnikami, które w określony sposób wyznaczyły treść wolności religijnej zawartej w konstytucjach. Istotny wpływ na normatywne ujęcie tych praw w konstytucjach miały ratyfikowane umowy międzynarodowe w zakresie ochrony praw człowieka, a także doświadczenia państw Europy, które oddziaływały na Amerykę Łacińską.

System ochrony wolności religijnej w państwach latynoamerykańskich jest w fazie tworzenia. Rzadko zdarza się, by akty niższego rzędu (ustawy) doprecyzowywały to prawo. Uwarunkowania społeczne (duża liczba katolików) powodują, że nie ma nacisku społecznego na zmiany prawne. A dopiero to dałoby impuls do ukształtowania sprawnie działającego systemu instytucjonalnego i proceduralnego celem pełnej ochrony wolności sumienia i religii.

Marta Osuchowska, Aleksandra Syryt The constitutional basis for religious freedom
in Selected countries in Europe and Latin America

Religion helps man keep his own identity. It enables him to participate in a common heritage. The study provides the constitutional basis for religious freedom in the individual dimension in selected countries in Europe and Latin America. The authors discuss the provisions on religious freedom enshrined in the constitutions of Italy, Spain and Portugal, as well as Argentina, Chile and Colombia.

The analysis leads to the conclusion that religious freedom is a human right protected both in the constitutions of European countries as well as in the constitutions of Latin American countries. 
:::: M. Osuchowska, A. Syryt, Konstytucyjne podstawy wolności...

The inclusion of the provisions on religious freedom in the individual dimension in the constitutions is due to certain similarities of the system of European and Latin American. Common features of both systems is that Europe and Latin America belong to the so-called Western civilization. The legal systems of Latin American countries formed primarily on the basis of Roman law.

Although the wording of the provisions on religious freedom in the individual dimension in the constitutions of Latin American countries is similar to the editorial rules of the constitution states of Europe, in practice there are other ways to implement this freedom and guarantees its protection. 